\title{
INFLUENCE OF EXTERNAL RESISTANCE AND ANODIC pH ON POWER DENSITY IN MICROBIAL FUEL CELL OPERATED WITH B. SUBTILIS BSC-2 STRAIN
}

\author{
Córdova-Bautista, Y. ${ }^{1}$ - Paraguay-Delgado, F. ${ }^{2}$ - PÉrez Hernández, B. ${ }^{3}$ - PÉrez \\ HERNÁNDEZ, G. ${ }^{1}-$ MARTÍNEZ PEREYRA, G. ${ }^{1}-$ RAMÍREZ MORALES E. ${ }^{* 1}$ \\ ${ }^{I}$ Universidad Juárez Autónoma de Tabasco, Avenida Universidad S/N, Zona de la Cultura, Col. \\ Magisterial, Centro, Villahermosa, Tabasco 86040, México \\ (e-mail: Yolanda.cordova@ujat.mx,cordovab@hotmail.com) \\ ${ }^{2}$ Centro de Investigación en Materiales Avanzados, Miguel de Cervantes 120, Chihuahua, \\ Chihuahua 31136, México \\ ${ }^{3}$ Laboratorio de pre-secuenciación del Instituto de Ecología A. C., El Haya, CP 91070 Xalapa, \\ Veracruz, México \\ *Corresponding author \\ e-mail:erik.ramirez@ujat.mx,eriking10@hotmail.com \\ (Received $25^{\text {th }}$ Nov 2017; accepted $19^{\text {th }}$ Mar 2018)
}

\begin{abstract}
Microbial fuel cells (MFCs) are bioelectrochemical devices able to convert chemical energy into electricity. The selection of anodic $\mathrm{pH}$ and external resistances play a significant role in the overall performance of the device. This research presents the effect of operational conditions of the MFC using B. Subtilis in anode. The effect of $\mathrm{pH}$ and external resistance were determined by $3^{2}$ full factorial design. Data were analyzed statistically by ANOVA and $\mathrm{p} \leq 0.05$ was considered statistically significant. The surface response analysis evidenced interaction and quadratic effect of the $\mathrm{pH}$ and external resistance on the power density generation. With a second-order polynomial model the optimum conditions of the system were determined. It maximized the power at $\mathrm{pH}$ of 8.6 and an external resistance of $220 \Omega$, delivering power density of $405 \mathrm{~mW} / \mathrm{m}^{2}$. The chemical oxygen demand (COD) removal efficiency and coulombic efficiency (CE) were $82 \%$ and $15 \%$, respectively. The maximum specific growth $(\mu)$ and substrate uptake $\left(k_{l}\right)$ rate for electrochemically active bacteria (EAB) at optimum conditions were $0.19 / \mathrm{h}$ and $0.019 / \mathrm{h}$ respectively. These experimental results show the importance of the simultaneous effect of $\mathrm{pH}$ and external resistance, which is even more influential then if they were studied separately.
\end{abstract}

Keywords: bioenergy, electrochemically active bacteria, $3^{2}$ full factorial design, bioelectrochemical system, kinetics modelling

\section{Introduction}

The amount of research about renewable energy is increasing, due to the inadequate supply of fossil fuels and their negative effects on environment and the economy. One promising technology is MFC. It can be used to produce bioelectricity, hydrogen or to remediate contaminants. A typical MFC device has two chambers which are anode and cathode, both are separated by a proton exchange membrane (PEM) (Logan, 2008). MFC is considered sustainable for bioenergy generation, because it produces electricity from organic waste through the direct oxidation of EAB. They grow in the anode chamber where the organic matter is oxidized to produce electrons and protons, with $\mathrm{CO}_{2}$ and biomass as final products. Electron transport to the anode is either direct, through physical contact of the microbes via cytochromes or nanowire structure, or indirect, via a soluble redox active mediator (Roy et al., 2014). To date, many EABs have been reported in MFC researches, including Shewanella (Ringeisen et al., 2006), 
Pseudomonas (Jayapriya and Ramamurthy, 2012), Escherichia (Zhang et al., 2006), Enterobacter (Nimje et al., 2011), Klebsiella (Zhang et al., 2008), Citrobacter (Huang et al., 2015), Desulfuromonas (Holmes et al., 2004), Geobacter (Nevin et al., 2008), Rhodoferax (Chaudhuri and Lovley, 2003), Clostridium (Park et al., 2001), Bacillus (Wu et al., 2014), Tolumonas (Lou et al., 2013), Corynebacterium (Liu et al., 2010) and Kocuria (Luo et al., 2015).

EAB plays a crucial role on the performance of MFCs. Therefore, it is important to know the EABs growth behaviour under different environmental conditions. Modelling of bacterial growth kinetics describe the behaviour of microorganism. Currently, both models Monod and Gompertz correspond to a universal model. However, the Monod model is fitted with a poorer correlation. The Gompertz model has been widely applied to describe the asymmetrical sigmoid shape of microbial growth, due to being statistically accurate and easy-to-use, when compared to other sigmoidal functions (Gil et al., 2011). The models used to describe growth may or may not be coupled with substrate uptake. The Monod model has a wide range of applications in nutrient removal kinetic for batch cultures. Although Monod kinetic in substrate uptake has been successfully applied, some research shows that this model to anaerobic processes is rather difficult. In this study complex structure models were avoided. Thus, the first order model proposed by Sarioglu and Gökçek (2016) was used.

On the other hand, the selection of suitable anodic $\mathrm{pH}$ could be crucial for the EAB grown and it affects the efficient proton motion through the PEM. In addition, the external resistance in MFC regulates the anode potential, enabling to the EAB the balance of the electrode reduction kinetics with the potential energy to gain available growth of the EAB (Nimje et al., 2011; González et al., 2014). To Understand the influence factors that improve the performance of MFCs mathematical modelling can be applicated. The Models of MFCs are classified into two main groups, namely Mechanism-based models and Application-based models. The Mechanism-based models are based on different bioelectrochemical reactions in an MFC. Those include bulk liquid models, electrochemical models, biofilm models and special models. Although the complexity limits the practical application of these models. The Application-based models are divided into the Electrical model and the Learning and controlling model (Xia et al., 2018). The Learning and controlling aspects are mainly used to optimize the output power, which contributes to improve the development of MFCs application. These models need an experimental design approach (MartínezConesa et al., 2017). Then, it is necessary to study factors such as anodic $\mathrm{pH}$ and external resistance which maximize power output of the MFC using B. subtilis BSC-2 strain as EAB.

In the present research the influence of two independent variables were evaluated: anodic $\mathrm{pH}$ and external resistance on power density (dependent variable). Further, it was aimed to optimize independent variable using surface response methodology (RSM) to achieve adequate response of MFC. For this purpose, data were collected by mathematical and statistical techniques to build the empirical model. These values could be used to analyse the interaction of different factors on dependent variables (Jia et al., 2014; Madani et al., 2015; Myers et al., 2016).

The growth and substrate uptake kinetic parameters of $B$. subtillis were evaluated under optimal conditions, finding optimized values which could be used for future design and simulations of MFCs. 


\section{Materials and methods}

\section{Bacterial strain}

The bacterial strain was isolated from the wastewater collected from a sugar factory, located in R/a Santa Rosalía Cárdenas, Tabasco, Mexico $\left(18^{\circ} 05^{\prime} 46.5^{\prime \prime} \mathrm{N}\right.$ and $\left.93^{\circ} 21^{\prime} 45.9^{\prime \prime} \mathrm{W}\right)$. The wastewater samples were taken from 10 randomly selected points. For each selected point $1 \mathrm{~L}$ of the sample was collected in autoclaved glass bottle. Subsequently the samples were transported inside a cooler to the biotechnology laboratory, where they were kept at $4^{\circ} \mathrm{C}$ before use (APHA, 2012). Then ten $\mathrm{mL}$ of each sample were inoculated in Erlenmeyer flasks containing $90 \mathrm{~mL}$ of sterile distilled water. For counting viable bacteria, this suspension was serially diluted in triplicate and 0.1 $\mathrm{mL}$ of suspension was spread on nutrient agar plates by spread plate method (Madigan et al., 2012). The plates were incubated at $28{ }^{\circ} \mathrm{C}$ for $72 \mathrm{~h}$. The bacterial isolates were then characterized at colony level (Kumar, 2015).

\section{Bacterial strain identification}

The Gram reaction was determined using violet crystal and safranin, afterwards the stained cells were observed by optical microscope (VE-BC1, VELAB Microscopes Inc). The morphology of each bacterial strain was observed through micrographs that were taken by scanning electron microscope JEOL JSM-6010LA (Hitachi, Tokyo, Japan) according to Holmes et al. (2004). The KIT API 20 E and 50 CH (BioMérieux) were used for the biochemical and physiological characterization of the strains according to the manufacturer's instructions.

Genomic DNA from each strain was isolated using the ZR Fungal / Bacterial DNA Miniprep extraction kit (D605). The V3-V5 region of the 16S rRNA gene was amplified using the primers 16sV3-V5F-TACGGRAGGCAGCAG- and 16sV3-V5RCCGTCAATTCMTTTGAGTTT. Each PCR reaction contained $200 \mathrm{uM}$ DNTPs (Deoxyribonucleotide triphosphates), $0.2 \mathrm{uM}$ of each $1 \mathrm{u}$ Mytaq Pol enzyme primer (Bioline). The amplification was carried out on the Thermocycler C1000 Touch Thermal Cycler (BIORAD) using the following PCR conditions: $94{ }^{\circ} \mathrm{C} 3 \mathrm{~min} 1 \mathrm{cycle}$, 35 cycles of $94{ }^{\circ} \mathrm{C} 30 \mathrm{~s}, 55^{\circ} \mathrm{C} 30 \mathrm{~s}$ and $72{ }^{\circ} \mathrm{C} 60 \mathrm{~s}$. A final extension of $72{ }^{\circ} \mathrm{C}$ for $5 \mathrm{~min}$. The PCR product was checked on a 1.5\% agarose gel (sigma A9539) stained with Midori Green Advanced (Nippon Europpe Genetics) and visualized by UV light. PCR products were purified using the Wizard SV Gel and PCR Clean-Up System kit (Promega). Sequencing of PCR products was performed by Macrogen Inc. in Seoul, South Korea using an automated sequencer ABI3730 XL (Applied Biosystem). The sequence (raw sequence) was analyzed in the program sequencer version 5.4. (GeneCodes). The sequences were compared to the available sequences in the nucleotide database of the National Center for Biotechnology Information (NCBI) using the local search tool (BLASTn).

\section{Inoculum preparation}

Under axenic conditions the BSC-2 isolate microbial was extracted from the agar plate with bacteriological handle, then it was placed in the Erlenmeyer flask with nutrient broth containing $8 \mathrm{~g}$ of meat extract per liter of water. Fermentation was maintained for two days at $37^{\circ} \mathrm{C}$. Subsequently the cell biomass was separated from the broth by centrifugation at $5000 \mathrm{rpm}$ for $20 \mathrm{~min}$. Then they were washed three times 
with buffer solution (sodium phosphate buffer $50 \mathrm{mM}$ at $\mathrm{pH}$ 7.0). Finally, the washed biomass was suspended in $10 \mathrm{~mL}$ of buffer solution (Luo et al., 2015). After, the suspension was used as inoculum to the MFC experiment.

\section{MFC construction and operation}

By triplicate, a modified double-chamber MFC was constructed from Logan method (Logan, 2008; Fig. 1), it was made using polypropylene (PP5) bottles with an approximate working volume of $700 \mathrm{~mL}$. Both chambers were attached by a chlorinated polyvinyl chloride (CPVC) bridge connected to a union nut of the same material, which contained a $2 \mathrm{~cm}$ diameter nafion 117 proton exchange membrane (Fuel Cell inc., USA). To prevent leakage in both chambers, CPVC nuts were used with rubber packing of $1.3 \mathrm{~cm}$ in diameter. The anode was carbon felt with $8 \mathrm{~cm}$ diameter and $1 \mathrm{~cm}$ thickness. The cathode was $5 \times 5 \mathrm{~cm}^{2}$ (40\% Pt, $0.3 \mathrm{mg} \mathrm{cm} 2$, Fuel Cell Inc., USA). Before use, electrodes were treated to remove impurities as follows: the anode was immersed in $1 \mathrm{~mol} / \mathrm{L} \mathrm{HCl}$ solution for $24 \mathrm{~h}$ and then in $1 \mathrm{~mol} / \mathrm{L} \mathrm{NaOH}$ solution for $3 \mathrm{~h}$ at the end it was rinsed with distilled water for several times (Liu et al., 2010). The cathode was immersed previously in acetone for $24 \mathrm{~h}$ and then in distilled water by overnight (Madani et al., 2015). These two electrodes were firmly connected into an external unit by thin copper-aluminium alloy wire $(0.6 \mathrm{~mm}$ diameter $)$. The surface exposure of the wire was isolated with epoxy resin to prevent corrosion.

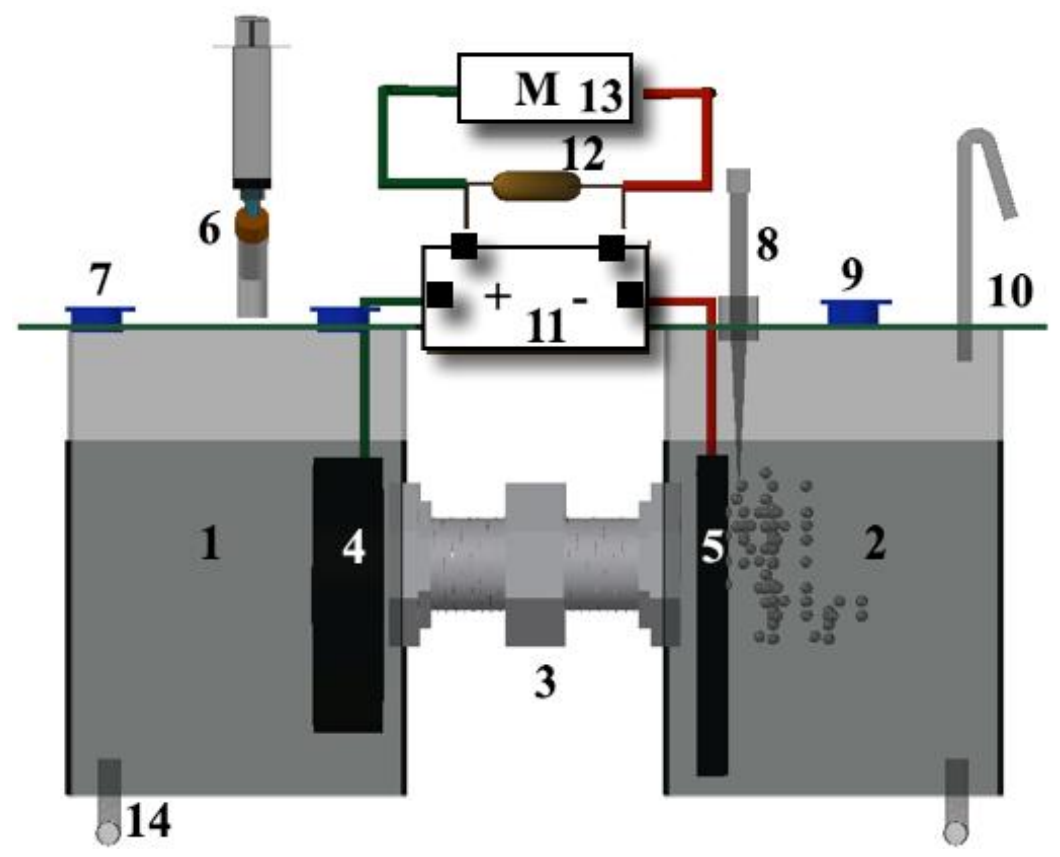

Figure 1. Schematic representation of the double chamber MFC. 1) Anodic chamber; 2)

Cathodic chamber; 3) Proton exchange membrane (PEM); 4) Anode electrode; 5) Cathode electrode; 6) sample taking; 7) Influent; 8) Air inlet; 9) Buffer influent; 10) Atmospheric vent;

11) Blinker board; 12) external resistance; 13) Digital multimeter; 14) Effluent.

The anode chamber was completely sealed by gaskets to create a completely anaerobic condition. The fuel used for this chamber was synthetic sugar wastewater (Pradeed et al., 2014). The anode chamber was filled with $600 \mathrm{~mL}$ of synthetic sugar 
wastewater, $100 \mathrm{~mL}$ of $52 \mathrm{mM}$ phosphate buffer solution $\left(\mathrm{K}_{2} \mathrm{HPO}_{4}, 5.4 \mathrm{~g} / \mathrm{L}\right.$ and $\mathrm{KH}_{2} \mathrm{PO}_{4}, 2.6 \mathrm{~g} / \mathrm{L} ; \mathrm{pH}$ 7) (Madani et al., 2015) and $10 \mathrm{~mL}$ liquid microbial inoculum. Bacterial concentration in the anolyte of anode chamber was determined by measuring its optical density at $660 \mathrm{~nm}\left(\mathrm{OD}_{660}\right)$ with the GENESYS 20 model spectrophotometer (Thermo Electron corp., USA). The initial $\mathrm{OD}_{660}$ of the anolyte was $0.006\left(37 \times 10^{3}\right.$ $\mathrm{UFC} / \mathrm{mL})$. Permanently it was maintained under anaerobic conditions. The cathode chamber was aerobic and it contained phosphate buffered at $82 \mathrm{mM}\left(\mathrm{K}_{2} \mathrm{HPO}_{4}, 8.8 \mathrm{~g} / \mathrm{L}\right.$ and $\mathrm{KH}_{2} \mathrm{PO}_{4}, 4.3 \mathrm{~g} / \mathrm{L}$; $\mathrm{pH}$ 7) (Madani et al., 2015) and it was aired continuously by an aquarium pump. The MFC was operated in a batch mode at room temperature $\left(25^{\circ} \mathrm{C}\right)$.

\section{Experimental design}

The present study used a three-level factor full factorial design for optimization and to find the adequate $\mathrm{pH}$ and external resistance values. Response surface graphics were used to study the factor interaction between the variables. The independent variables were the anodic $\mathrm{pH}\left(\mathrm{X}_{1}\right)$ and the external resistances $\left(\mathrm{X}_{2}\right)$. Three factorial levels were coded for low, medium and high settings (-1, 0 and +1 respectively) for two independent variables. A total of 9 experimental runs were required for analysing the interaction of each level on response variable (Table 1). The selected response investigated variable was the power density (Y) and it was analysed by multiple factorial regression analysis using the following quadratic model (Eq. 1):

$$
Y_{i}=b_{1} X_{1}+b_{2} X_{2}+b_{12} X_{1} X_{2}+b_{11} X_{1}^{2}+b_{22} X_{2}^{2}
$$

Where Yi stands for the responses; $b_{0}$ is the arithmetic mean response of all trials; and $b_{1}$ is the estimated coefficient for factor $X_{1}$. The main effects, $X_{1}$ and $X_{2}$, represent the average value of changing factor one at a time; $\mathrm{X}_{1} \mathrm{X}_{2}$ represent the interaction terms and the polynomial terms $\mathrm{X}_{21}$ and $\mathrm{X}_{22}$ are used to assess nonlinearity. The statistical experimental design was analysed by using the software MINITAB® Release 14.12.0.

Table 1. Variables and their levels for $3^{2}$ full factorial design

\begin{tabular}{c|c|c}
\hline \multicolumn{3}{c}{ Independent variables } \\
\hline Coded value & $\mathbf{p H}$ & Resistance ( $\mathbf{\text { }})$ \\
\hline Low (-1) & 7 & 47 \\
Medium (0) & 8 & 100 \\
High (+1) & 9 & 220 \\
\hline
\end{tabular}

Dependent variable: power density $\left(\mathrm{mW} / \mathrm{m}^{2}\right)$

\section{Analytical measurement and calculation}

Voltage was continuously measured by a multimeter (aplabvc97), the current intensity was determined using Ohm's law (Eq. 2) and power density was obtained according to Equation 3.

$$
I=\frac{V}{R}
$$




$$
\text { Power density }=\frac{V^{2}}{A \times R}
$$

where, $\mathrm{V}$ is the potential (volts), $\mathrm{I}$ is the current intensity, $\mathrm{A}$ is electrode surface area (square meter), $\mathrm{R}$ is external resistance $(\Omega)$.

The concentration of the total sugar was determined by the phenol-sulfuric acid method using sucrose as the standard solution (Dubios et al., 1956). In the anode chamber, the COD $(\mathrm{mg} / \mathrm{L})$ were analysed by closed reflux colorimetric method as mentioned in Standard Methods (APHA, 1998). Liquid samples were centrifuged at $8000 \mathrm{rpm}$ for $5 \mathrm{~min}$ and the supernatants were used for measurement. CE is defined as the fractional recovery of electrons from the substrate, it was calculated using Equation 4 (Logan et al., 2006):

$$
C E=\frac{M \int_{0}^{t} I d t}{n \times v \times F\left(C O D_{0}-C O D_{t}\right)} \times 100
$$

where $\mathrm{M}$ is the molecular weight of oxygen, I is the current, $\mathrm{F}$ is Faraday's constant (98, $485 \mathrm{C} /$ mol-e), $\mathrm{n}=4$ is the number of electrons exchanged per mole of oxygen, and $\mathrm{v}$ is the anolyte volume, CODo is the influent COD, CODt the effluent COD and t is time.

To monitor bacterial growth, samples were withdrawn aseptically at each $1 \mathrm{~h}$ interval and cell growth was monitored by $\mathrm{OD}_{600}$. Which was converted to colony forming units (CFU) using a pre-established calibration curve (UFC/mL vs OD at $600 \mathrm{~nm}$ ). The growth and substrate uptake rates were obtained by non-linear regression analysis, fitting Gompertz model (Eq. 5) and First order model (Eq. 7) to experimental data respectively (Okpokwasili and Nweke, 2005; Sarioglu and Gökçek, 2016).

$$
\log _{(t)}=A+C e^{-e[-B(t-M]}
$$

where $\mathrm{N}(\mathrm{t})$ is the population density at time $\mathrm{t}[\mathrm{Log}(\mathrm{CFU} / \mathrm{mL})]$, A stands for the microbial counts when the time lowered indefinitely; it is equivalent to the initial bacteria level, $\mathrm{C}$ stands for the microbial counts when the time increased indefinitely, $\mathrm{M}$ is the time at which the exponential growth rate is maximal (h) and B is the relative growth rate at $\mathrm{M}$ time. The growth rate $(\mu)$ can be obtained using Equation 6:

$$
\mu=(B x C) / e
$$

The substrate uptake rate $\left(k_{l}\right)$ that is the kinetic constant for substrate uptake, can be obtained from Equation 7:

$$
S_{t}=S_{0} e^{-k_{1} t}
$$

\section{Results and discussion}

\section{Phenotypic and genotypic characteristics of isolates bacteria}

Isolation of bacteria was carried out in nutrient agar culture medium, where macroscopic characterization at the colony level allowed to observe strains with circular and irregular shapes, whitish, round and wavy, flat and convex elevation. Cells were 
Gram-positive and the micrographs show that the bacteria have an oval shape with 1.2 to 1.4 and 1.4 to $1.6 \mu \mathrm{m}$ dimensions for BCC-1 and BSC-2 strain respectively (Fig. 2). Both BCC-1 and BSC-2 strain were positive for the catalase and nitrate reduction tests. The BSC-2 strain can ferment mannose, sorbitol, arabinose, rhamnose, ribose, glucose and sucrose. The BCC-1 strain can ferment ribose, glucose and sucrose, but it cannot ferment mannose, sorbitol arabinose and rhamnose (Table 2). Such characteristics indicate that they are genus Bacillus bacteria, moreover due to the difference in carbohydrates fermentation, it can be said that these are two species of Bacillus.

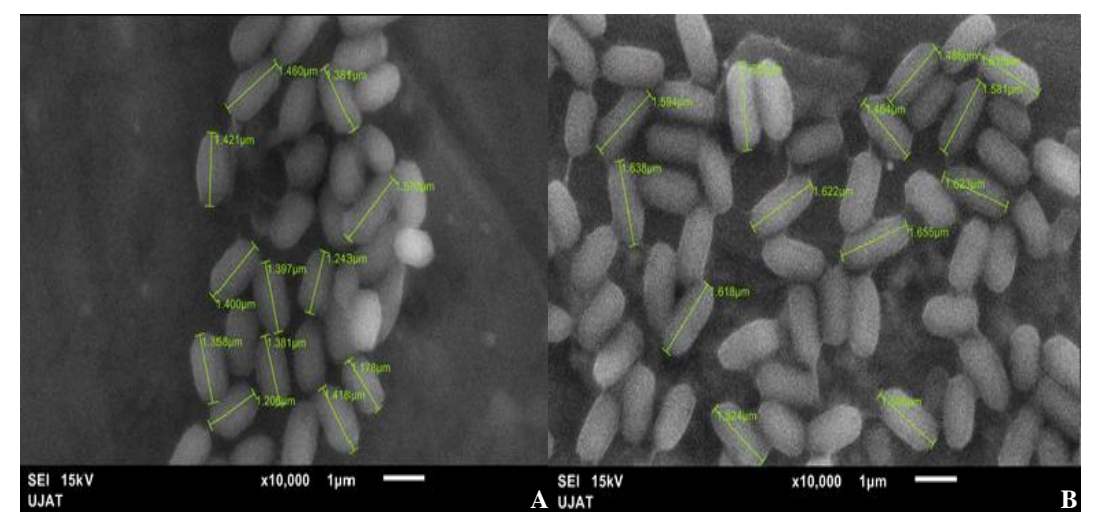

Figure 2. SEM micrographs for A) BCC-1 and B) BSC-2

Table 2. Phenotypic characteristics of bacterial strains

\begin{tabular}{|c|c|c|}
\hline Characteristics & BCC-1 (B. Cereus) & BSC-2 (B. Subtilis) \\
\hline Shape & Circular & Irregular \\
\hline Colour & Whitish & Whitish \\
\hline Edge & Round & Wavy \\
\hline Elevation & Convex & Flat \\
\hline Consistency & Viscose & Dry and Rough \\
\hline Microscopic characteristics & $1.2-1.4 \mu \mathrm{m}$ & $1.4-1.6 \mu \mathrm{m}$ \\
\hline Catalase & + & + \\
\hline Oxidase & - & - \\
\hline Nitrate & + & + \\
\hline Mannose & - & + \\
\hline Sorbitol & - & + \\
\hline Arabinose & - & + \\
\hline Rhamnose & - & + \\
\hline Ribose & + & + \\
\hline Glucose & + & + \\
\hline Sucrose & + & + \\
\hline
\end{tabular}


After the BLAST search the sequence analysis of the $16 \mathrm{~S}$ ribosomal gene confirmed that BCC-1 strain showed a 99\% likeness with the Bacillus cereus sequence (KX170761.1) and BSC-2 strain a 99\% similarity to Bacillus subtilis (GQ392049.1). Hence, BCC-1 and BSC-2 were designated as B. cereus and B. Subtilis respectively. However, because B. cereus is considered by the Food and Drug Administration (FDA) as a pathogenic organism (Tallent et al., 2012) its use in this work was ruled out. Thus, $B$. subtilis was selected only, since it is widely used in the food and pharmaceutical industry (Zhu et al., 2015). Additionally, the B. subtilis sequences were deposited on the Genebank under the accession number KY508314.

\section{Optimization by factorial design}

The factorial design was used to investigate the effect of $\mathrm{pH}$ and external resistance on power density. Table 3 shows the data obtained for the experimental trial and the values of power density were fitted in the design to get the model equations for the response variable.

Table 3. Full factorial design with their experimental coded level of independent variables observed response values

\begin{tabular}{c|c|c|c}
\hline \multirow{2}{*}{ Batch no. } & \multicolumn{2}{|c|}{ Levels of independent variables (factors) } & Dependent variable (response) \\
\cline { 2 - 4 } & $\mathbf{p H}, \mathbf{X}_{\mathbf{1}}$ & Resistance $(\mathbf{\Omega}), \mathbf{X}_{\mathbf{2}}$ & Power density $\left(\mathbf{m W} / \mathbf{m}^{\mathbf{2}}\right)$ \\
\hline $\mathrm{MFC}_{1}$ & -1 & -1 & $059.42 \pm 3.03^{\mathrm{a}}$ \\
$\mathrm{MFC}_{2}$ & -1 & 0 & $037.89 \pm 1.09$ \\
$\mathrm{MFC}_{3}$ & -1 & 1 & $121.39 \pm 2.12$ \\
$\mathrm{MFC}_{4}$ & 0 & -1 & $006.91 \pm 0.77$ \\
$\mathrm{MFC}_{5}$ & 0 & 0 & $327.64 \pm 58.85$ \\
$\mathrm{MFC}_{6}$ & 0 & 1 & $313.65 \pm 19.00$ \\
$\mathrm{MFC}_{7}$ & 1 & -1 & $002.70 \pm 0.63$ \\
$\mathrm{MFC}_{8}$ & 1 & 0 & $002.21 \pm 0.97$ \\
$\mathrm{MFC}_{9}$ & 1 & 1 & $416.10 \pm 86.77$ \\
\hline
\end{tabular}

${ }^{\mathrm{a}}$ Mean $\pm \mathrm{SD}, \mathrm{n}=3 .+1$ : higher values, 0 : medium values, -1 : lower values

The full model equation relating to the power density as response is:

Power density $\left(\mathrm{mW} / \mathrm{m}^{2}\right)=250.50+45.92 X_{1}+130.35 X_{2}-109.45 X_{1}^{2}-24.17 X_{2}^{2}+93.19 X_{1} X_{2}$

Statistical testing model was developed with the Fisher statistical test for ANOVA. Table 4 shows the values Prob $>\mathrm{F}$ of all regression model terms that were less than 0.05 , which indicates, model terms are significant at a confidence interval of $95 \%$. Also, the model F-value of 18.18 implies that the quadratic model is significant. The lack-of-fit test describes the variation of the fitted model. The model has non-significant lack-of-fit value $(\mathrm{F}$-value $=4.87, \mathrm{p}<0.05)$, indicating a significant correlation between the factors and response (Myers et al., 2016).

Model simplification was carried out by eliminating non-significant terms ( $\mathrm{p}>0.05)$ in the above model equation ( $E q .7)$, now giving the following equation $(E q .8)$ :

$$
\text { Power density }\left(\mathrm{mW} / \mathrm{m}^{2}\right)=232.81+45.92 X_{1}+127.81 X_{2}-109.45 X_{1}^{2}+93.19 X_{1} X_{2}
$$


As the model was generated by taking only the significant terms from the full model, the results are deduced by interpreting the reduced model. Table 5 shows the effect of factors and associated $\mathrm{p}$ values for power density, for both full model and reduced model.

The coefficients in the regression with more than one factor term represent an interaction term. A positive value represents a synergistic effect which favours optimization, while a negative sign indicates an antagonistic effect or inverse effect between the factors and the response (Sarabia and Ortiz, 2009). Thus, for the reduced model the regression equation $(E q .8)$ and Table 5 show that power density was significantly influenced by synergistic effect of $\mathrm{pH}$, the resistance as well as interaction term $\mathrm{X}_{1} \mathrm{X}_{2}$ ( $\mathrm{pH}$ x resistance) with $\mathrm{p}$-value of $0.032,0.000$ and 0.001 , respectively. While the quadratic term of $\mathrm{pH}$ has a negative effect on power density with $\mathrm{p}$-value of 0.004 . The results indicate that the increase in power density is the consequence of the strong interaction between the $\mathrm{pH}$ and the resistance. Furthermore, the $\mathrm{pH}$ values demonstrated a quadratic effect on power density which indicates that optimal levels of $\mathrm{pH}$ are inside of the experimental region.

Table 4. ANOVA results of quadratic model for power density

\begin{tabular}{c|c|c|c|c|c}
\hline Source & df & Sum of squares & Mean square & F-value & P-value \\
\hline Model & 4 & 511072 & 127768 & 18.18 & $0.000^{\mathrm{a}}$ \\
Linear & 2 & 329622 & 173106 & 24.63 & 0.000 \\
Square & 1 & 71872 & 71872 & 10.22 & 0.004 \\
Interaction & 1 & 109578 & 109578 & 15.59 & 0.001 \\
Residual Error & 22 & 154646 & 7029 & & \\
Lack-of-Fit & 4 & 131904 & 32976 & 4.87 & 0.056 \\
Pure Error & 5 & 22742 & 6763 & & \\
Total & 26 & 665718 & & & \\
\hline
\end{tabular}

${ }^{\mathrm{a}}$ Significant terms at $\mathrm{p}<0.05, \mathrm{R}-$ Squared $=86 \%$ and Adj R-Squared $=84 \%$

Table 5. The factor effects of full model and reduced model for power density

\begin{tabular}{c|c|c|c|c|c|c}
\hline \multirow{2}{*}{ Factor } & \multicolumn{3}{|c|}{ Full model } & \multicolumn{3}{c}{ Reduced model } \\
\cline { 2 - 7 } & $\mathbf{X}$ coefficient & $\mathbf{t}$ & P-value & X coefficient & $\mathbf{t}$ & P-value \\
\hline $\mathrm{X}_{1}$ & 45.92 & 2.261 & $0.035^{\mathrm{a}}$ & 45.92 & 2.296 & 0.032 \\
$\mathrm{X}_{2}$ & 130.35 & 6.495 & $0.000^{\mathrm{a}}$ & 127.81 & 6.632 & 0.000 \\
$\mathrm{X}_{1} \mathrm{X}_{2}$ & 93.19 & 3.888 & $0.001^{\mathrm{a}}$ & 93.19 & 3.948 & 0.001 \\
$\mathrm{X}_{1}{ }^{2}$ & -109.45 & -3.148 & $0.005^{\mathrm{a}}$ & -109.45 & -3.198 & 0.004 \\
$\mathrm{X}_{2}{ }^{2}$ & -24.17 & -0.573 & 0.573 & - & - & - \\
Intercept & 250.50 & 5.964 & $0.000^{\mathrm{a}}$ & 232.81 & 8.297 & 0.000 \\
\hline
\end{tabular}

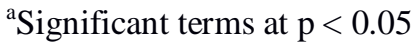

\section{Response surface and contour plot}

The MRS approach is a helpful tool for developing, improving and optimizing process as it allows elucidating the relationship between the dependent and independent variables (Sarabia and Ortiz, 2009; Myers et al., 2016). The response surface and 
contour plot are very useful to illustrate and understand the main, interaction and quadratic effects on maximum power density. The response surface and contour graphs of the effects of $\mathrm{pH}$ and resistance that produced maxima power density is shown in Figure $3 A$ and $3 B$. It can be observed that the curvature introduced by quadratic term $(\mathrm{pH})$ and that the power density presents a maximum value. Figure $3 \mathrm{~A}$ also shows the tendency of the power density to increase as the resistance increases. The results presented a maximum value obtained for an intermediary value between $\mathrm{pH} 8$ and $\mathrm{pH} 9$ for the different resistances considered. However, the maximum value is observed between 150 and $220 \Omega$. It is clear that the $\mathrm{pH}$ value has strong effect on production power density because during microbial growth the enzymatic reaction that occurs in the microbial body has an optimum $\mathrm{pH}$. Environmental changes in $\mathrm{pH}$ affect the active center of the enzyme and the state of ionization of substrate molecule and enzyme molecule, thus the combine of enzyme and substrate is affected. The higher or lower $\mathrm{pH}$ values will influence the stability of the enzyme that could be damaged irreversibly, which results in bacterial inactivation. In addition, the $\mathrm{pH}$ value also affects metabolism and absorption of nutrients through influencing the stability of membrane structure and solubility of nutrients, thus affecting the growth rate of microorganisms. Because any microorganisms should live in an appropriate $\mathrm{pH}$ value, microbial growth can be inhibited when the $\mathrm{pH}$ microenvironment is below or above of the appropriate $\mathrm{pH}$ value (Madigan et al., 2012). Furthermore, the selection of anodic $\mathrm{pH}$ value ensures the efficient movement of protons through PEM due to the driving force for the anode reaction increases with an increasing anolyte $\mathrm{pH}$, this improves the diffusion of protons through membrane. The positive effects of alkaline $\mathrm{pH}$ in the power density using MFCs has been reported previously (Liu et al., 2010; Rago et al., 2016).

Moreover, the external resistance in the MFC directly influences the anode availability as an electron acceptor. In addition, it also exerts a selective pressure on the electrogenic bacterial community. Since a low external resistance (50 to $500 \Omega$ ) promotes growth and metabolic activity of the microorganisms then electron transport to the cathode is facilitated (Lyon et al., 2010). Zhang et al. (2011) mentioned that external resistance appropriate in MFC regulates the anode potential, enabling the electrogenic microorganisms to balance the reduction electrode kinetics with potential energy gain and thus reduces losses by activation. In this work, increasing the $\mathrm{pH}$ value from 7 to 9 with external resistance of $220 \Omega$ the power density was enhanced nearly to 3.4 times (from 121.3 to $416.10 \mathrm{~mW} / \mathrm{m}^{2}$ ). These results revealed that the interaction effect between $\mathrm{pH}$ and resistance was remarkable, then the effect of $\mathrm{pH}$ on power density generation was highly depended on the level of the external resistance.

Figure $3 B$ shows the contour plot, the contour areas represent constant responses, which correspond to power density from 0 to $400 \mathrm{~mW} / \mathrm{m}^{2}$. It was determined from the contour that maximum power density higher to $400 \mathrm{~mW} / \mathrm{m}^{2}$ could be obtained with $\mathrm{pH}$ range between 8.5 and 8.8 with external resistance of $220 \Omega$. Hence, by equation $(E q .8)$ the location of optimum was determined for $\mathrm{pH}$ of 8.6 and an external resistance of 220 $\Omega$. The maximum value of power density at this point was estimated to be $405 \mathrm{~mW} / \mathrm{m}^{2}$. In order to confirm the predicted results of the model, the experiment verification was made for three times under optimal conditions. The average of maximum power density was $402.55 \pm 2.63 \mathrm{~mW} / \mathrm{m}^{2}$ with small error-values of -0.6 . This reveals that mathematical model obtained from the $3^{2}$ factorial design was adequate. The optimized MFC was characterized by COD removal efficiency, coulombic efficiency, growth kinetics and substrate uptake of B. subtilis. 

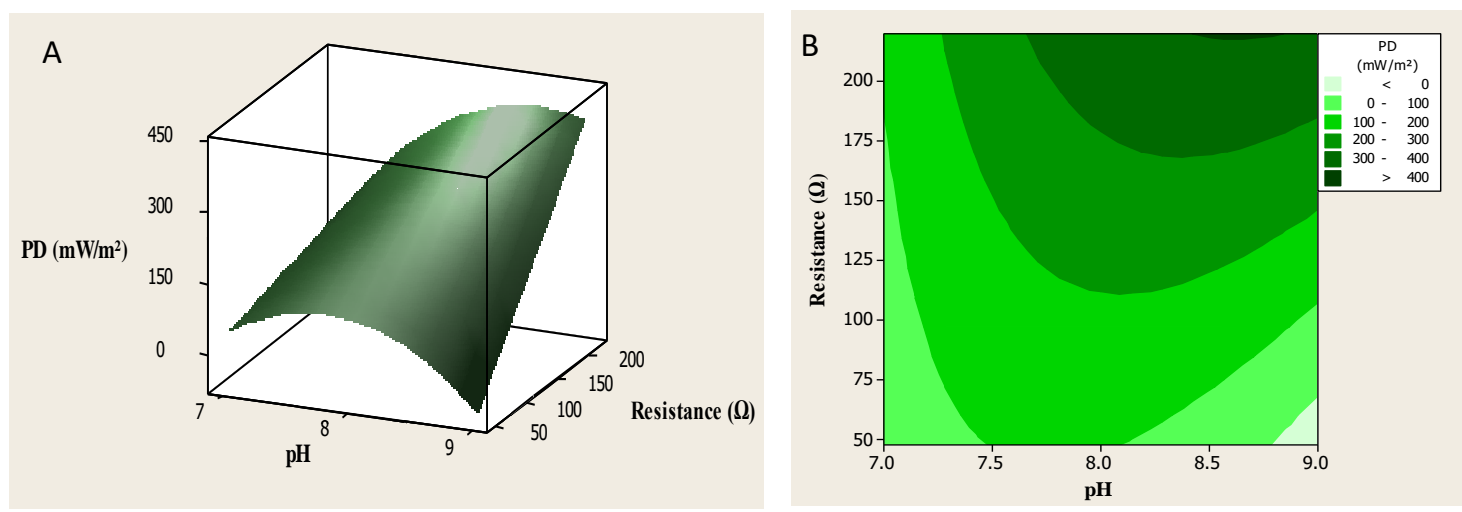

Figure 3. A: Response surface plot for power density. B: Contour plot for power density

\section{COD removal and coulombic efficiency}

In the MFC operated with anodic $\mathrm{pH}$ of 8.6 and resistance $220 \Omega$, the average COD of the synthetic wastewater effluent was $524.5 \pm 10 \mathrm{mg} / \mathrm{L}$. Since the COD in the effluent was $3009 \pm 32 \mathrm{mg} / \mathrm{L}$, the COD removal efficiency was $82 \%$. CE represents the conversion efficiency of organic compounds to an electric charge. In this research, the average $\mathrm{CE}$ was $15 \pm 1.26 \%$ indicating that $15 \%$ of the available electrons in the removed substrate were used for current production. These operating conditions might be responsible for the substrate degradation by $B$. subtilis due to its growth and metabolism, which results in high COD removal efficiency. However, the low efficiency coulombic might be because of the metabolite production in the anodic chamber or also low electron transfer efficacy due to such limitations associated with electrodes as the difficulty of accessibility of electrons to anode or cathode as a deposition of interfering or insulating substances on electrodes. Similar results were obtained for L. sphaericus, it produced a coulombic efficiency of $12.69 \%$ in a double chamber MFC using lactate as substrate and with proteinaceous substrate the COD removal was about 74\% (Nandy et al., 2013; He et al., 2014). In that regard in a MFC with $E$. cloacae to $\mathrm{pH} 8.5$ in anodic chamber $65 \%$ of the COD was removed and the coulombic efficiency was $3 \%$. Therefore, $B$. subtillis BSC-2 used in MFC is effective at COD removal as well as in current production.

\section{Determination of $\mu$ and $k_{1}$ for B. subtilis in optimized MFC}

The kinetic parameters $\mu$ and $k_{l}$ was determined by curve-fitting of date with Gompertz and First order model, respectively. The Figure $4 A$ shows that observed date gave a reasonably good fit to the $B$. subtilis kinetic growth described by Equation 5 . In addition, the high determination coefficient $\left(\mathrm{R}^{2}=0.98\right)$ value shows the ability of this model in describing the $B$. subtilis growth kinetics. The growth rate of $B$. subtilis obtained in MFC operated with anodic $\mathrm{pH}$ of 8.6 and resistance of 220 was $0.19 / \mathrm{h}$. Figure $4 B$ shows the sucrose consumption and the fitted model by Equation 7 . The coefficient of determination $\mathrm{R}^{2}=0.97$ shows that the model had an excellent fit to the experimental results, obtaining $k_{1}=0.019 / \mathrm{h}$. Miroliaei et al. (2015) investigated the kinetics of pure cultures of E. coli and Shewanella sp. in an air cathode MFC, the kinetics parameters were predicted using Monod and Moser models. To E. coli the determination coefficient $\mathrm{R}^{2}$ was found to be 0.92 for Moser model and 0.94 for Monod model. To Shewanella sp. the determination coefficient $\mathrm{R}^{2}$ was 0.90 and 0.94 for Moser 
and Monod models, respectively. To E. coli the maximum specific growth rate with Monod model was $0.42 / \mathrm{h}$. And to Shewanella $s p$. the maximum specific growth rate with Monod model was $1.54 / \mathrm{h}$. Zhang et al. (2013) studied the nitrate degradation in anodic denitrification microbial fuel cell (AD-MFC). This study was supported by four degradation kinetics models, i. e. Haldane $\left(\mathrm{R}^{2}=0.79\right)$, Edwards $\left(\mathrm{R}^{2}=0.83\right)$, Luong $\left(\mathrm{R}^{2}=0.97\right)$ and Hand-Levenspiel $\left(\mathrm{R}^{2}=0.99\right)$. Hand-Levenspiel model was selected as the best model. Therefore, the selecting of suitable model in the modelling of bacterial growth and substrate uptake may depend on the kind of microorganism, anolyte characteristics and operating conditions etc. (Okpokwasili and Nweke, 2005; Sarioglu and Gökçek, 2016).
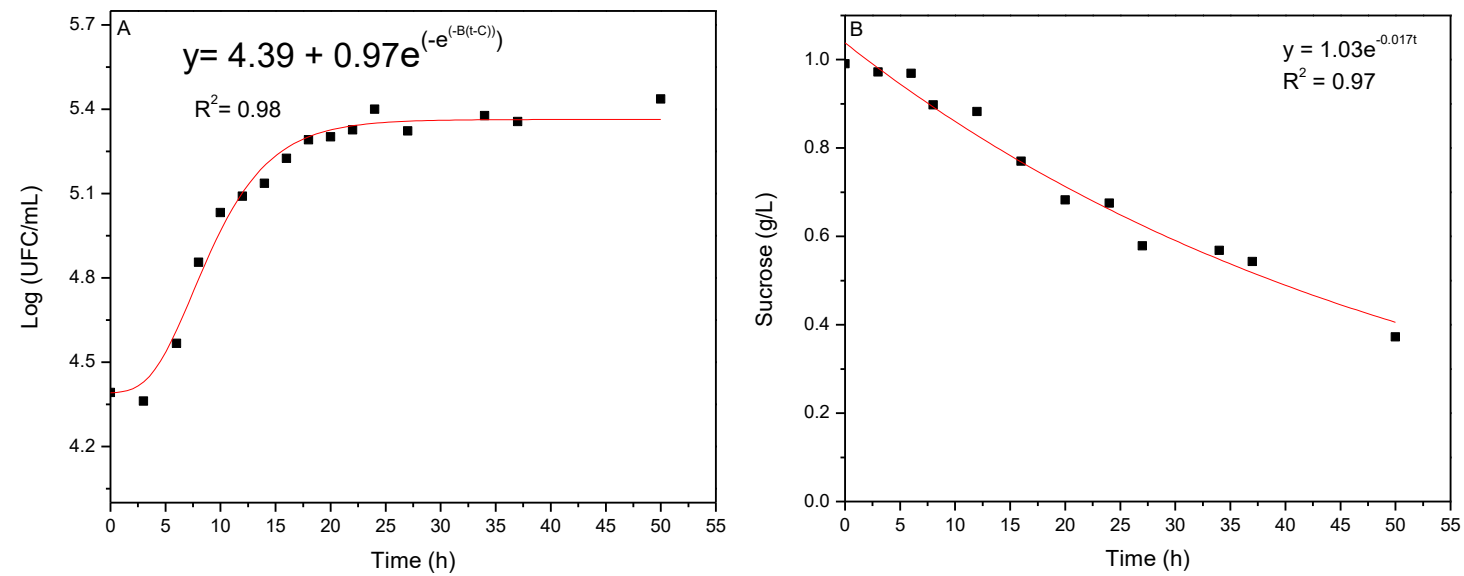

Figure 4. A: B: subtilis growth value and the fitted model by Equation 5. B: Sucrose concentration value and fitted model by Equation 7

\section{Conclusion}

This study examines the effects of the $\mathrm{pH}$ and the external resistance on the performance of dual chambered MFC in maximizing the power density. Using $3^{2}$ full factorial design, the effects of independent variables were studied and optimized. Checking the validity of the model, the statistical indicator $\mathrm{p}$-value was determined to be statistically adequate. Based on MSR a quadratic polynomial equation was developed. It is noteworthy that, in this research the maximum power density (405 $\mathrm{mW} / \mathrm{m}^{2}$ ) of the MFC was significantly influenced by the $\mathrm{pH}$ and the external resistance and the optimal conditions were selected: anodic $\mathrm{pH}$ of 8.6 and external resistance of $220 \Omega$. The model terms for power density are significant to predict the power density based upon the $\mathrm{pH}$ and the external resistance. Furthermore, electrochemically active $B$. subtilis BSC-2 strain has the ability to remove the $82 \%$ of the COD synthetic sugar wastewater and produce clean energy. The Gompertz and First order kinetic models gave high determination coefficient, for growth and substrate uptake, respectively. More MFC models are expected to be developed in the future due to their great advantages for optimization, especially for the practical application of MFC technology for simultaneous production of energy and water treatment. 


\section{REFERENCES}

[1] APHA (1998): Standard Methods for the Examination of Water and Wastewater, 20th ed. - American Public Health Association/American Water Works Association/Water Environment Federation, Washington DC.

[2] APHA/AWWA/WEF (2012): 9060 Samples. Standard Methods for the Examination of Water and Wastewater. 22nd edition. - American Public Health Association, American Water Works Association, Water Environment Federation, Washington, DC.

[3] Chaudhuri, S. K., Lovley, D. R. (2003): Electricity generation by direct oxidation of glucose in mediatorless microbial fuel cells. - Nat. Biotechnol. 21: 1229-1232.

[4] Dubios, M., Gilles, K. A., Hamilton, J. K., Rebers, P. A., Smith, F. (1956): Colorimetric method for determination of sugars and related substances. - Anal. Chem. 28: 350-356.

[5] Gil, M. M., Miller, F. A., Brandão, T. R. S., Silva, C. L. M. (2011): On the use of the Gompertz model to predict microbial thermal inactivation under isothermal and nonisothermal conditions. - Food Eng. Rev. 3: 17-25.

[6] González, C. A. del, Cañizares, P., Lobato, J., Rodrigo, M., Fernández, M. F. J. (2014): Effects of External Resistance on Microbial Fuel Cell's Performance. - Lefebvre, G., Jiménez, E., Cabañas, B. (eds.), Enviroment, Energy and Climate Change II, pp. 175-196. Springer International Publisher, Switzerland.

[7] He, H., Yuan, S. J., Tong, Z. H., Huang, Y. X., Lin, Z. Q., Yu, H. Q. (2014): Characterization of a new electrochemically active bacterium, Lysinibacillus sphaericus D-8, isolated with a WO3 nanocluster probe. - Process Biochem. 49: 290-294.

[8] Holmes, D. E., Bond, D. R., Lovley, D. R. (2004): Electron transfer by Desulfobulbus propionicus to $\mathrm{Fe}(\mathrm{III})$ and Graphite electrodes. - Appl. Environ. Microbiol. 70(2): 12341237.

[9] Huang, J., Zhu, N., Cao, Y., Peng, Y., Wu, P., Dong, W. (2015): Exoelectrogenic Bacterium phylogenetically Related to Citrobacter freundii, isolated from anodic biofilm of a microbial fuel cell. - Appl. Biochem. Biotechnol. 175: 1879-1891.

[10] Jayapriya, J., Ramamurthy, V. (2012): Use of non-native phenazines to improve the performance of Pesudomonas aeruginosa MTCC 2474 catalysed fuel cells. - Bioresour. Technol. 124: 23-28.

[11] Jia, Q., Wei, L., Han, H., Shen, J. (2014): Factors that influence the performance of twochamber microbial fuel cell. - Int. J. of Hydrogen Energ. 39: 13687-13693.

[12] Kumar, S. (2015): Texbook of Microbiology for Bsc Nursing. 1st ed. - Jaypee Brother Medical Publishers, New Delhi.

[13] Liu, M., Yuan, Y., Zhang, X. L., Zhuang, L., Zhou, S. G., Ni, J. R. (2010): Bioelectricity generation by a Gram-positive Corynebacterium sp. strain MFC03 under alkaline condition in microbial fuel cells. - Bioresour. Technol. 101(6): 1807-1811.

[14] Logan, B. E. (2008): Microbial Fuel Cells. - John Wiley \& Sons Inc, New Jersey, USA.

[15] Logan, B. E., Hamelers, B., Rozendal, R. A., Schrorder, U., Keller, J., Freguia, S., Aelterman, P., Verstraete, W., Rabaey, K. (2006): Microbial fuel cells: Methodology and technology. - Environ. Sci. Technol. 40: 5181-5192.

[16] Luo, J., Yang, J., He, H., Jin, T., Zhou, L., Wang, M., Zhou, M. (2013): A new electrochemically active bacterium phylogenetically related to Tolumonas osonensis and power performance in MFCs. - Bioresour. Technol. 139: 141-148.

[17] Luo, J., Li, M., Zhou, M., Hu, Y. (2015): Characterization of a novel strain phylogenetically related to Kocuria rhizophila and its chemical modification to improve performance of microbial fuel cells. - Biosens. Bioelectron. 69: 113-120.

[18] Lyon, D. Y., Buret, F., Vogel, T. M., Monier, J. M. (2010): Is resistance futile? Changing external resistance does not improve microbial fuel cell performance. Bioelectrochemistry. 78: 2-7. 
[19] Madani, S., Gheshlaghi, R., Mahdavi M, A., Sobhani, M., Elkamel, A. (2015): Optimization of the performance of a double-chamber microbial fuel cell through factorial design of experiments and response surface methodology. - Fuel. 150: 434-440.

[20] Madigan, M. T., Martinko, M. J., Dunlap, P. V., Clark, D. P. (2012): Brock Biology of Microorganisms.12 ed. - Pearson, San Francisco.

[21] Martínez-Conesa, E. J., Ortiz-Martínez, V. M., Salar-García, M. J., Delos Rios, A. P., Hernández-Fernández, F. J., Lozano, L. J., Godínez, C. (2017): A Box-Behnken designbased model for predicting power performance in microbial fuel cells using wastewater. Chem. Eng. Commun. 204: 97-104.

[22] Miroliaei, M. R., Samimi, A., Mohebbi-Kalhori, D., Khorram, M. (2015): Kinetics investigation of diversity cultures of E. coli and Shewanella sp., and their combined effect with mediator on MFC performance. - J. Ind. Eng. Chem. 25: 42-50.

[23] Myers, R. H., Montgomery, D. C., Anderson-Cook, C. (2016): Response Surface Methodology. 4th ed. - John Wiley \& Sons, Hoboken, USA.

[24] Nandy, A., Kumar, V., Kundu, P. P. (2013): Utilization of proteinaceous materials for power generation in a mediatorless microbial fuel cell by a new electrogenic bacteria Lysinibacillus sphaericus VA5. - Enzyme Microb. Technol. 53: 339-344.

[25] Nevin, K. P., Richter, H., Covalla, S. F., Johnson, J. P., Woodard, T. L., Orloff, A. L., Jia, H., Zhang, M., Lovley, D. R. (2008): Power output and columbic efficiencies from biofilms of Geobacter sulfurreducens comparable to mixed community microbial fuel cells. - Environ. Microbiol. 10: 2505-2514.

[26] Nimje, V. R., Chen, C. Y., Chen, C. C., Tsai, J. Y., Chen, H. R., Huang, Y. M., Jean, J. S., Chang, Y. F., Shih, R. C. (2011): Microbial fuel cell of Enterobacter cloacae: Effect of anodic $\mathrm{pH}$ microenvironment on current, power density, internal resistance and electrochemical losses. - Int. J. Hydrog. Energy 36(17): 11093-11101.

[27] Okpokwasili, G. C., Nweke, C. O. (2005): Microbial growth and substrate utilization kinetics. - Afr. J. Biotechnol. 5: 305-317.

[28] Park, H. S., Kim, B. H., Kim, H. S., Kim, H. J., Kim, G. T., Kim, M., Chang, I. S., Park, Y. K., Chang, H. I. (2001): A novel electrochemically active and Fe (III)-reducing bacterium phylogenetically related to Clostridium butyricum isolated from a Microbial Fuel Cell. - Anaerobe 7: 297-306.

[29] Pradeed, N. V., Vidyashree, K. G., Pooja, J., Anupama, S., Laskshmi, P., Arun Kumar, J. M., Ankitha, K. (2014): Treatment of sugar industry wastewater in anaerobic downflow stationary fixed film (DSFF) reactor. - Sugar Tech. 16(1): 9-14.

[30] Rago, L., Baeza, J. A., Guisasola, A. (2016): Increase performance of hydrogen production in microbial electrolysis cells under alkaline conditions. Bioelectrochemistry. - 109: 57-62.

[31] Ringeisen, B. R., Henderson, E., Wu, P. K., Pietron, J., Ray, R., Little, B., Biffinger, J. C., Meehan-Jones, J. M. (2006): High power density from a miniture microbial fuel cell using Shewanella oneidensis DSP10. - Environ. Sci. Technol. 40(8): 2629-2634.

[32] Roy, J. N., Babanova, S., Garcia K. E., Cornejo, J., Ista, L. K., Atanassov, P. (2014): Catalytic biofilm formation by Shewanella Oneidensis MR.1 and anode characterization by expanded uncertainty. - Electrochim. Acta. 126: 3-10.

[33] Sarabia, L. A., Ortiz, M. C. (2009): Response Surface Methodology. - In: Brown, S. D., Tauler, R., Walczak, B. (eds.) Comprehensive Chemometrics. Chemical and Biochemical Data Analysis, Section 1.12, pp. 345-390. Elsevier, Amsterdam.

[34] Sarioglu, M. C., Gökçek. O. B. (2016): Treatment of automotive industry wastewater using anaerobic batch reactors: The influence of substrate/inoculum and molasses/wastewater. - Process Saf. Environ. Prot. 102: 648-654.

[35] Tallent, S. M., Kotewicz, K. M., Strain, E. A., Bennett. R. W. (2012): Efficient isolation and identification of Bacillus cereus group. - J. AOAC Int. 95(2): 446-451. 
[36] Wu, S., Xiao, Y., Wang, L., Zheng, Y., Chang, K., Zheng, Z., Yang, Z., Varcoe, J. R., Zhao, F. (2014): Extracellular electron transfer mediated by flavins in Gram-positive Bacillus sp. WSXY1 and yeast Pichia stipitis. - Electrochim. Acta. 146: 564-567.

[37] Xia, C., Zhang, D., Pedrycz, W., Zhu, Y., Guo, Y. (2018): Models for microbial fuel cells: A critical review. - J. Power Sources 373: 119-131.

[38] Zhang, J., Zheng, P., Zhang, M., Chen, H., Chen, T., Xie, Z., Cai, J., Abbas, G. (2013): Kinetics of substrate degradation and electricity generation in anodic denitrification microbial fuel cell (AD-MFC). - Bioresour. Technol. 149: 44-50.

[39] Zhang, L., Zhou, S., Zhuang, L., Li, W., Zhang, J., Lu, N., Deng, L. (2008): Microbial fuel cell based on Klebsiella pneumoniae biofilm. - Electrochem. commun. 10: 16411643.

[40] Zhang, L., Zhu, X., Li, J., Qiang, L., Ye, D. (2011): Biofilm formation and electricity generation of a microbial fuel cell started up under different external resistances. - J. Power Sources. 196: 6029-6035.

[41] Zhang, T., Cui, C., Chen, S., Ai, X., Yang, H., Shen, P., Peng, Z. (2006): A novel mediatorless microbial fuel cell based on direct biocatalysis of Escherichia coli. - Chem. Commun. 21: 2257-2259.

[42] Zhu, Y., Liu, Y., Li, J., Shin, H-D., Du, G., Liu, L., Chen, J. (2015): An optimal glucose feeding strategy integrated with step-wise regulation of the dissolved oxygen level improves $\mathrm{N}$-acetylglucosamine production in recombinant Bacillus subtilis. - Bioresour. Technol. 177: 387-392. 